\title{
CATOLICISMOS E MEMÓRIA NO RIO GRANDE DO SUL
}

\author{
Carlos Alberto Steil \\ Universidade Federal do Rio Grande do Sul
}

\begin{abstract}
Resumo: O presente artigo faz uma leitura histórica da trajetória do catolicismo no Estado do Rio Grande do Sul a partir das romarias contemporâneas que mantêm e atualizam uma tradição de longa duração. Tomando como base o método das escavaçôes, busca perceber como esses eventos têm servido como suporte de uma memória coletiva que, ao relacionar tempo e espaço, também oferece recursos simbólicos e discursivos para a permanente atividade de interpretação da realidade pelos grupos sociais.
\end{abstract}

Palavras-chave: catolicismo, cultura popular, peregrinação, Rio Grande do Sul.

Keywords: Catholicism, pilgrimage, popular culture, Rio Grande do Sul.

O catolicismo no Rio Grande do Sul tem uma trajetória de quase 500 anos que, em linhas gerais, se confunde com a história social e política do próprio estado. As mudanças que são observadas no processo de formação do estado vão pari passu com aquelas que ocorrem no catolicismo. Este, no entanto, não apenas reflete essas mudanças, mas também oferece, em grande medida, os recursos simbólicos e discursivos para a sua interpretação, assim como o suporte para a memória coletiva. De modo que nos propomos aqui a destacar alguns aspectos que estão presentes nos rituais de peregrinação contemporâneos e que nos remetem para os sentidos que foram sendo construídos pela sociedade gaúcha em diferentes momentos de sua história com os recursos da religião, enquanto uma estrutura de significados, e particularmente do catolicismo, enquanto religião dominante. Nesse sentido, nossa premissa interpretativa é de que a memória coletiva foi selecionando alguns elementos dessa experiência e a retém inscrevendo-os nos 
rituais de peregrinação que se realizam em grande número no estado todos os anos, mobilizando milhares de pessoas.

O último censo populacional estima um contingente de 7.807.640 católicos no Estado do Rio Grande do Sul, numa população total de 10.187.798 habitantes. ${ }^{1}$ Ou seja, $76,5 \%$ dos gaúchos se reconheciam como católicos em 2000. Embora esse índice, como têm mostrado os dados dos últimos censos, venha caindo a cada ano, a grande maioria da população no estado ainda é constituída por católicos. Por outro lado, o número de participantes nos eventos de peregrinaçóes e de turismo religioso que conseguimos registrar em nossa pesquisa parece crescer a cada ano, chegando a mais de quatro milhões de pessoas em 2000. ${ }^{2}$ Em termos comparativos, dados da Embratur registram um número de 15 milhões de romeiros que freqüentam anualmente os centros de peregrinação no país.

Há, portanto, um peso significativo das peregrinações no conjunto das práticas do catolicismo no estado. Os bispos e dirigentes católicos, ao que tudo indica, não só têm consciência disso, mas nos últimos anos têm feito grandes investimentos para divulgar, incrementar e controlar esses eventos. Observamos um envolvimento do aparato eclesiástico institucional da Igreja Católica, por meio do Regional da CNBB, das dioceses e paróquias na promoção das romarias. Ao longo da pesquisa, pudemos observar ainda como outras instâncias e organismos institucionais, como colégios, universidades, congregações religiosas, também acabam contribuindo para a realização dos eventos de romarias.

Por fora do aparato institucional, no entanto, articula-se um outro sistema bastante extenso de práticas e crenças religiosas que, embora faça parte do universo católico, não goza do reconhecimento oficial da Igreja. Esse sistema, geralmente denominado de catolicismo popular tradicional, tem como sua principal base de sustentação a devoção aos santos, com os

\footnotetext{
${ }^{1}$ Dados da pesquisa do IBGE de 2000.

2 Optamos por não incluir nesse universo os turistas que participam do Natal Luz e Sonho de Natal em Gramado e Canela, visto que estes fogem do perfil dos romeiros que estamos construindo.
} 
quais os fiéis estabelecem relações de aliança - seus santos padroeiros, como Santo Antônio e São Cristóvão - e/ou de trocas, nas quais predominam as promessas e obrigações mais imediatas. As romarias são parte constitutiva destes dois subsistemas que formam o catolicismo que, como sabemos, é maior do que a Igreja Católica, embora mantenha com esta uma relação de complementaridade tão estreita que faz com que instituição e movimento se confundam num todo.

O catolicismo se torna compreensível na medida em que é visto no horizonte de sua trajetória histórica. Uma interpretação dos eventos das romarias no estado deverá, portanto, assumir uma perspectiva de longa duração. Pudemos ver, então, como diferentes experiências religiosas, associadas a momentos históricos e culturais específicos, foram sedimentando diferentes estruturas de significados que deram densidade e heterogeneidade ao catolicismo.Essas estruturas, no entanto, não se sucedem no tempo como pontos contíguos dentro de uma linha, mas convivem na contemporaneidade, colocando em disputada uma grande variedade de símbolos e signos. Numa alusão ao método da escavação, cabe ao antropólogo apontar nos eventos e símbolos acionados no presente as camadas históricas que os constituem. Nesse sentido, as romarias no Rio Grande do Sul são um locus privilegiado da memória histórica, na medida em que elas tendem a encenar diferentes experiências históricas do catolicismo como símbolo, mito e história, reinscrevendo o passado na textualidade do presente.

\section{O CATOLICISMO MODERNO DE ORIGEM IBÉRICA}

Uma primeira estrutura de sentidos que podemos observar nas romarias contemporâneas no estado traduzem fundamentalmente uma experiência moderna do catolicismo, que tem suas fontes no cristianismo ibérico do século XVI. Seu ato fundante pode ser localizado no Concílio de Trento (1545-1563), que durante cerca de quatro séculos regulamentou a vida religiosa dos países católicos e atribuiu aos prelados a obrigação de instruir os seus fiéis (Châtellier, 1995). No início dos tempos modernos (séculos 
XVI a XVIII) muitos missionários, sobretudo jesuítas e franciscanos, percorreram a Europa, enquanto outros se ocupavam da evangelização da Ásia e da América. É este catolicismo moderno, centrado na figura dos missionários e na experiência histórica das reduções jesuíticas, localizadas ainda em território da América espanhola, que vai constituir o núcleo de um dos mitos de fundação do estado e de evangelização cristã. ${ }^{3}$

Duas romarias especialmente estão associadas a essa experiência: a dos Mártires do Caaró e a Romaria da Terra. ${ }^{4}$ Em ambas vamos perceber o mesmo esforço, embora com sentidos diversos, de fazer uma leitura projetiva do passado mítico e histórico como traduções e transvalorizações possíveis da experiência presente. Caaró, centrada na figura dos missionários jesuítas, busca reafirmar o papel da instituição e do catolicismo na formação do estado. A Romaria da Terra, ao evocar a figura do índio mítico e heróico Sepé Tiaraju, vai afirmar a possibilidade da contestação ao poder dominante e a legitimidade das ocupaçôes de terra, realizadas por colonos do Movimento Sem-Terra, através de uma narrativa que constrói uma linha de continuidade entre sujeitos e signos do passado e atores e agentes sociais marginalizados do presente: índios, negros, colonos sem-terra. Estes tendem a ser colocados, pelo discurso dominante, como um "outro" em relação aos sentidos e valores de uma identidade nacional ou gaúcha, que é elaborada pelo folclore e pela história dos heróis. Nesse sentido, a Romaria da Terra é um lugar privilegiado de elaboração social de uma outra narrativa, pensada também como uma totalidade, do que é ser gaúcho e do que é ser brasileiro.

${ }^{3}$ É preciso lembrar aqui que nesse período o território que hoje constitui o Estado do Rio Grande do Sul estava sob o domínio espanhol.

${ }^{4}$ Caaró é uma romaria que está associada ao martírio dos santos jesuítas Roque González, Afonso Rodriguez e João del Castillo, que trabalharam nas missões jesuítas no século XVII e morreram pelas mãos dos índios. Esses mártires foram canonizados por João Paulo II em 1988. Já a Romaria da Terra é uma romaria itinerante que é promovida especialmente pela pastoral popular por meio da Comissão Pastoral da Terra (CPT), com uma forte conotação política, na linha da Teologia da Libertação. 
A segunda experiência histórica do catolicismo no Rio Grande do Sul também se situa no marco do início da modernidade. Sua origem é ibérica, mas vem de Portugal. Não está centrada na figura do missionário, como a espanhola, mas se estrutura a partir das irmandades ou devoções, no meio urbano, e dos beatos e monges, no meio rural. Essas instituições e agentes religiosos, de caráter leigo, são, em grande parte, responsáveis pela implantação e manutenção do culto aos santos, eixo organizador da vida religiosa até a primeira metade do século XIX no Brasil.

Num contexto em que a presença institucional da Igreja Católica é fraca, as irmandades ou devoçôes vão ocupar um lugar central na reprodução do catolicismo, consolidando uma estrutura de poder religioso e político por fora do aparelho eclesiástico. O que vai dar origem aos conflitos e tensões dentro do catolicismo, a partir do final do século XIX, quando a Igreja Católica reorienta sua atuação, com o intuito de afirmar sua presença institucional na sociedade brasileira através do controle clerical sobre as formas do culto devocional. Conflitos que vão se evidenciar particularmente no espaço dos santuários que haviam sido criados e controlados pelas irmandades ou devoções. O santuário de Nossa Senhora dos Navegantes, em Porto Alegre, é uma das experiências mais expressivas desse tipo de catolicismo. ${ }^{5} \mathrm{O}$ acompanhamento desse evento não nos revela apenas antigos conflitos entre a irmandade e a cúria diocesana, mas mostra que esses conflitos se modificam ao longo do tempo, incorporando novos atores religiosos e políticos e complexificando o campo das disputas pelos significados e valores condensados na imagem e na romaria de Nossa Senhora dos Navegantes. Poderíamos falar, tomando como referência os trabalhos de Marshall Sahlins sobre a relação entre história e antropologia, de "uma estrutura de significados que quan to mais permanece, mais se modifica" (Sahlins, 2000, p. 68, tradução minha).

${ }^{5}$ A romaria de Nossa Senhora dos Navegantes acontece no dia 2 de fevereiro, em Porto Alegre, e é o evento que congrega o maior número de pessoas no estado, chegando a reunir um milhão de pessoas. Trata-se de um ritual sincrético, com grande participação de membros e simpatizantes das religiōes afro-brasileiras, que cultuam Iemanjá na figura e imagem de Nossa Senhora dos Navegantes. 
Se os santuários urbanos estiveram centrados nas irmandades, as romarias que surgiram no meio rural estão, de um modo geral, associadas a figura dos penitentes, que constituem um movimento leigo de busca da natureza e dos lugares ermos como espaços privilegiados de comunicação com o sagrado. Entre as romarias no estado, a do Morro do Botucaraí é exemplar deste tipo de experiência religiosa. ${ }^{6}$ O Monge João Maria é, nesse sentido, uma figura emblemática deste movimento de espiritualidade penitencial. Embora de origem italiana e tendo vivido na segunda metade do século XIX, este ermitão se torna representante e mediador de um sistema de crenças e valores presentes de forma difusa na população "cabocla", formada por negros e descendentes de portugueses e ibéricos em meio aos grupos de migrantes alemães e italianos que se tornam dominantes na região?

Mas o que é característico desse catolicismo? Que aspectos o tornam uma experiência singular e o diferenciam de outras formas de catolicismo? A experiência do Monge João Maria salienta três aspectos fundamentais que poderiam ser estendidos para o conjunto das práticas partilhadas por estes grupos sociais de origem cabocla e que poderíamos chamar de catolicismo tradicional: sua origem laica, seu sentido devocional e seu caráter penitencial.

É um catolicismo laico porque não depende de um corpo especializado de agentes religiosos para se reproduzir. Enquanto sistema religioso se apresenta menos como uma instituição com fronteiras demarcadas e mais como uma experiência que permeia a vida e a cultura. Ser católico, nesse contexto popular tradicional, não se apresentava como uma opção ou uma escolha individual, mas como uma condição a que todos estavam de certa

${ }^{6}$ A romaria do Cerro Santo está associada ao Monge João Maria de Agostini, que viveu como ermitão no século XIX no morro do Botucaraí, no município de Candelária, e permaneceu na memória popular como a primeira encarnação de uma sucessão de monges e beatos que estão na origem de diversos movimentos religiosos de contestação à modernização do país e da Igreja Católica. Entre eles estão os dois monges do Contestado (SC), o monge de Pinherinho (RS) e os monges barbudos de Soledade (RS).

7 O termo "caboclo" está sendo usado aqui em seu sentido êmico, que é definido em oposição aos de "origem", que têm ascendência italiana e alemã. 
forma submetidos. O catolicismo se apresentava assim como uma cultura englobante, de modo que as outras formas religiosas que existiam na época, como as religiōes afro-brasileiras, eram vistas como práticas desviantes da religião única e oficial.

A devoção às imagens é central para o catolicismo tradicional. São, na verdade, o lugar onde o invisível se torna acessível e palpável. Da mesma forma que os corpos humanos são depositários das almas invisíveis, as imagens são os corpos dos santos. Através das imagens se estabelece uma comunicação entre vivos e mortos. Fundado no dogma da comunhão dos santos, esse modelo de catolicismo cria uma cosmologia em que as fronteiras entre a vida e a morte são continuamente ultrapassadas sem necessariamente a mediação de agentes especializados. As relações entre os santos e os fiéis são pessoais e baseadas no princípio da proteção e lealdade. Cada fiel tem seu santo protetor, ou seu padrinho celestial, que em contrapartida the pede lealdade. Muitos estudiosos da cultura brasileira têm mostrado como esse modelo relacional não apenas serviu de base para legitimar as relações de dominação na sociedade senhorial no Brasil, mas permanece ainda hoje como um elemento cultural de longa duração, que subjaz às relações de clientelismo e patronagem ainda hoje tão presentes na política brasileira.

Os santos, na perspectiva do catolicismo tradicional, permanecem, de algum modo, participando das vicissitudes deste mundo através de suas imagens, capazes de sentir, chorar, sofrer, locomover-se, falar, indicar caminhos, etc. A imagem de um santo, portanto, não é apenas uma representação que evoca alguém que esteve entre os vivos, mas é "um sacramento". Algo que torna presente no mundo visível, de forma eficaz e real, personagens que transitam entre os vivos e os mortos. Ou seja, há uma relação entre a imagem e o santo que os torna uma única e mesma coisa. Por isso, os lugares e as imagens têm no catolicismo tradicional um sentido particular e uma singularidade que ultrapassa qualquer tentativa de racionalização ou generalização.

Enfim, trata-se de um catolicismo penitencial. A paixão está no centro desse modelo de catolicismo, estabelecendo uma relação singular entre o santo em sua imagem e os fiéis. A romaria do Monge no morro do Botucaraí 
acontece na Sexta-Feira da Paixão, quando a liturgia católica traz para o culto e performatiza as imagens da dor e da morte, estabelecendo uma dialética barroca em que os fiéis, identificando-se com o Cristo Sofredor, participam vicariamente da sua paixão. Por meio da penitência se realiza um processo de identificação entre o fiel e o santo. Ou seja, ser católico não é algo que se define pela adesão a um determinado corpo de verdades ou pela aceitação de um código moral, mas através da identificação com o sofrimento e a paixão.

Esta centralidade da Paixão, como podemos ver no caso do Monge João Maria, não está presente apenas na referência ao espaço, mas também ao tempo. A Quaresma, com seus rituais e memórias, traz a morte para dentro do presente, evocando, através da imagem do Monge Sofredor,identificado com o Bom Jesus, o triunfo da vida sobre a desintegração do corpo. Essa identificação pelo sofrimento que une ritualisticamente a experiência de Cristo, do Monge e do romeiro acaba diluindo as fronteiras entre vivos e mortos, permitindo aos fiéis tratar a morte não como a negação da vida, mas como sua transfiguração. A vida e a morte são, assim, remetidas a um contexto que as engloba, o da comunhão dos santos, que cria um espaço exemplar de convivência entre vivos e mortos.

\section{O CATOLICISMO DE IMIGRAÇÃO}

A terceira experiência que vai contribuir na formação do catolicismo no Rio Grande do Sul foi trazida pelos migrantes europeus, especialmente de origem italiana e alemã, e, com menor peso, pelos poloneses. Os migrantes não só reproduzem aqui o catolicismo que viviam em seus países de origem, mas o recriam, uma vez que já não contam com os mesmos recursos que tinham na Europa. Na ausên cia do "pároco da aldeia", foi preciso organizar as comunidades de migrantes em torno das capelas, dirigidas por uma diretoria de leigos, responsáveis pelo culto e pela organização das festas religi osas, centro da vida social destas comunidades. Aqui, o centro organizador do culto já não é a devoção, mas a capela, embora as devoções 
ocupem um lugar ainda importante na experiência religiosa individual e comunitária dos migrantes. De modo que a experiência de ser estrangeiro, ao impor a necessidade de uma afirmação de identidade étnica, desloca o culto da devoção para a comunidade.

A chegada da Europa das ordens e congregaçóes religiosas modernas no final do século XIX e início do XX vai permitir um avanço nesse processo de formação de um catolicismo moderno, centrado sobre a comunidade. Os franciscanos entre os italianos, e os jesuítas entre os alemães, vão reforçar o laço institucional das capelas com a Igreja Católica. Porém, tendo em vista a autonomia que essas ordens religiosas possuem dentro da instituição em relação ao seu núcleo burocrático, pode-se compreender a emergência de um pensamento antiinstitucional, no interior da instituição, permitindo os movimentos de contestação que surgem associados à Teologia da Libertação.

A estreita ligação entre fiéis e clero, especialmente religioso, está na origem de duas romarias que, de certa forma, performatizam essa aliança: a romaria do Padre Reus e a romaria do Frei Salvador. ${ }^{8}$ Duas figuras do mun-

${ }^{8}$ A devoção ao Padre Reus é possivelmente aquela que possui maior abrangência entre as devoçôes de origem local no estado, cruzando, inclusive, suas fronteiras e atingindo devotos em Santa Catarina e no Paraná. Padre Reus nasceu na Alemanha, ordenou-se padre e tornou-se jesuíta no início do século passado, vindo para o Brasil como missionário no início do século XX. Depois de sua morte passou a ser cultuado pelos católicos que passaram a freqüentar o seu túmulo. Mais tarde os jesuítas construíram um moderno templo, dedicado ao Sagrado Coração de Jesus, deixando ao túmulo um lugar de destaque, fora do templo. As romarias ao túmulo e santuário são constantes, com dois momentos de maior afluência de fiéis no dia 2 de novembro e na Sexta-Feira Santa. Já o Frei Salvador é um frade franciscano (não padre), filho de migrantes italianos, que viveu na segunda metade do século XIX na cidade de Flores da Cunha, na região dos vinhedos. Sua romaria acontece na festa de Corpus Christi, quando a cidade recebe um número expressivo de pessoas de fora para ver as ruas enfeitadas com os tapetes de serragem colorida e participar do evento turístico e religioso que tem lugar na parte da manhã. À tarde, acontece a procissão ao campanário da Virgem Maria, fora da cidade, que ficou associado ao Frei como o local para onde ele se retirava para rezar quando vivo. No culto ao Frei Salvador podemos ver uma tentativa de atualização da tradição do franciscanismo, associada à ecologia. Ambos os santos têm seu processo de beatificação aberto em Roma.

Debates do NER, Porto Alegre, ANo 5, N. 5, P. 9-30, JUnho 2004 
do clerical, que emergem nas duas grandes ordens religiosas que ocuparam o centro da formação do catolicismo de migração: Padre Reus, entre os jesuítas, e Frei Salvador, no meio franciscano. Ambos contam com grande simpatia entre os fiéis, que acorrem em grande número para visitar seus túmulos. Representam também dois modelos de espiritualidade e a dois modos de ser. O primeiro, remete a uma espiritualidade introspectiva e aos estereótipos do que é ser alemão no sul do país. O segundo, a uma espiritualidade ligada ao trabalho e aos estereótipos do italiano. De modo que, em algum sentido, pode-se pensar nestes santuários como demarcando identidades étnicas.

\section{O CATOLICISMO ROMANIZADO}

Outra camada de significados que dá densidade ao catolicismo nos remete ao movimento de restauração, promovido por Roma. Este alcança o Brasil na segunda metade do século XIX, já no segundo império, e tem na questão religiosa (1870), seu momento de maior visibilidade social. Esse movimento foi denominado por cientistas sociais e historiadores que estudaram esse período de romanização. ${ }^{9}$ Trata-se, em linhas gerais, de um movimento que buscava a reforma da Igreja no plano local e nacional e a centralização do seu governo pelo Vaticano. Em termos sociológicos, podese falar de uma ação modernizadora que tem como objetivo ajustar o catolicismo brasileiro a um modelo universal, definido por Roma. Seus traços essenciais são a espiritualidade centrada nos sacramentos e o controle do clero sobre o culto. Sua ideologia está fundada sobre "a noção de purifica-

9 A noção de romanização do catolicismo brasileiro foi sugerida por Roger Bastide (1951)e desenvolvida por Ralph Della Cava (1970) e Ribeiro de Oliveira (1985). Em seu estudo sobre o santuário do Padre Cícero, Miracle at Joaseiro, Della Cava usa esse conceito para compreender a emergência e desenvolvimento da romaria. Ainda em relação ao uso desse conceito aplicado aos estudos de peregrinações, também o uso na análise do culto no santuário de Bom Jesus da Lapa (Steil, 1996). 
ção do catolicismo popular tradicional de seus abusos e superstições" (Beozzo, 1977, p. 753). Seus promotores no Brasil foram fundamentalmente as ordens e congregações religiosas que vieram da Europa a partir da última década do século XIX. A sua estratégia de implantação consistiu basicamente na formação do clero em seminários e na organização do catolicismo a partir das paróquias e dioceses, substituindo a estrutura das irmandades.

Em relação aos santuários e romarias, o movimento de romanização concentrou sua ação na substituição de antigas devoções por devoções novas, ou que passaram por um processo de racionalização teológica, que permitia a sua universalização. Nesse quadro, o santuário de Lourdes, na França, reconhecido, promovido e controlado pelo clero, se torna o modelo para todos os santuários católicos no mundo. Tratava-se de enquadrar o discurso do milagre nos parâmetros de um discurso racional, que incorporava a educação como um elemento central para a vivência da fé. Ao mesmo tempo, buscava deslocar o centro do culto da imagem e do lugar para o sacramento e a instituição. Ao lado de Lourdes, aparece Fátima, devoção mariana de origem portuguesa, associada a outro santuário de abrangência internacional, que também será erigido em modelo para os demais santuários católicos. No contexto do catolicismo romanizado, vão surgir muitos santuários e romarias dedicados a Nossa Senhora de Lourdes e a Nossa Senhora de Fátima. A grande maioria deles, no entanto, não chega a se tornar expressiva no quadro das romarias no estado.

No Rio Grande do Sul, devido ao contexto do catolicismo de imigração, o movimento de romanização, de um modo geral, teve um significado e uma recepção diferentes daqueles que obteve noutras regiões do país, onde a estrutura do catolicismo popular tradicional tinha um peso muito maior. Os migrantes não só tiveram uma atitude positiva em relação à renovação, promovida desde Roma pelo clero de origem européia, como se identificaram em grande medida com ela por partilharem de uma origem comum e por falarem o mesmo idioma. As ordens e congregaçóes buscaram se implantar nas regiôes de colonizaçãocolocando padres italianos entre migrantes italianos e alemães entre migrantes alemães. Por outro lado, os filhos dos migrantesencontraram nos semináriosque surgiam uma oportunidadeúnica 
de ascensão social. O que vai dar origem a uma classe média com capital intelectual expressiva no estado, proveniente de estratos camponeses que passaram pelos seminários. Esse processo produz um diferencial na formação da classe média do estado em relação a outras regiōes do país, criando uma solidariedade muito estreita entre classe média urbana e os trabalhadores do campo. É nesse quadro que vamos compreender não só o surgimento dos novos movimentos sociais do campo no Sul, mas as características e traços que ele assume. A mesma solidariedade que vamos encontrar entre o clero, formado nestes seminários, e os camponeses sem-terra, muitos dos quais são parentes muito próximos: pais, irmãos, primos, sobrinhos que não ingressaram no seminário, muitas vezes por imposição da própria estrutura de parentesco, que determina quem deve ficar no campo para manter a terra ou cuidar dos pais.

Os desdobramentos do movimento de romanização e o surgimento da Teologia da Libertação não podem ser compreendidos fora desse contexto, onde o catolicismo romanizado do Sul, ao prover os novos quadros clericais da instituição, com a interrupção do vinda de padres europeus, não reproduz simplesmente o modelo e a ideologiade Roma, mas o recria e o reinventa. Nesse sentido, a posição de Roma contra a Teologia da Libertação no pontificado de João Paulo II e a reafirmação de um modelo centralizador da instituição, poderiam ser pensadas como uma reação às conseqüências não esperadas ou previstas da própria romanização.

\section{O CATOLICISMO LIBERTADOR}

Alcançamos, assim, mais uma camada de significados no nosso processo de escavação: o catolicismo libertador. Seus mitos de origem o associam ao movimento da Ação Católica, que precede a renovação do Vaticano II, e que no Brasil produziu algumas lideranças políticas expressivas, que vão ingressar em movimentos de contestação do regime militar. Muitas dessas lideranças foram perseguidas, presas, exiladas ou torturadas e mortas nos porōes da repressão. Também o Concílio Vaticano II (1963-1965), e suas 
versões latino-americanas, as Conferências do CELAM (Conselho Episcopal Latino-americano) de Medellin (Colômbia, 1968) e Puebla (México, 1979) são evocados como seus eventos fundantes. Sua expressão ideológica sistematizada é a Teologia da Libertação e sua experiência referencial, as Comunidades Eclesiais de Base (CEBs). Sua visibilidade social está associada ao papel que a Igreja Católica desempenhou no apoio e articulação dos movimentos sociais de contestação do regime militar, no contexto político dos anos 1970 e 1980. É essa interação com os movimentos sociais que vai então permitir o encompassamento pelo catolicismo no Brasil de um discurso político e social racionalizado.

Quanto às romarias, pode-se dizer que o catolicismo da libertação vai atuar não só no sentido da substituição do discurso do milagre pelo discurso sacramental, como se observa na romanização, mas também na diluição do seu núcleo mítico, através de uma racionalização que busca desconstruir a relação necessária entre sagrado e lugar e entre imagem e ação divina. Por outro lado, se o catolicismo romanizado buscava deslocar o sagrado do espaço geográfico para a instituição, ou da teofania para a mediação clerical, o catolicismo da libertação procura deslocá-lo da instituição para a sociedade, dos mediadores clericais para os mediadores políticos. $\mathrm{Na}$ linguagem teológica, esse movimento se expressa como um deslocamento da Igreja para o Reino de Deus. Ou seja, o político se torna o espaço da manifestação do "sagrado" e o compromisso com a "luta pela libertação", a sua mediação. Já não se trata nem de buscar um centro geográfico teofânico nem da mediação eclesial para alcançar um deus transcendente, mas de criar eventos sociais e políticos capazes de fortalecer a caminhada que deve conduzir ao não-lugar ou à utopia da "terra sem males". É no contexto desse catolicismo que podemos compreender o surgimento da Romaria da Terra e a Romaria dos Trabalhadores: sem centro geográfico, sem imagens de santos, sem milagres. Onde a própria instituição é relativizada frente a um "projeto" mais abrangente, que é o da construção da "sociedade liberta", ou o Reino de Deus que, como afirma a teologia, é maior do que a Igreja. 


\section{CATOLICISMO CARISMÁTICO}

Se as décadas de 1970 e 1980 foram do catolicismo da libertação, a década de 1990 foi marcada pelo movimento da Renovação Carismática Católica (RCC). Localizada, no seu início, nas franjas da instituição, a RCC pouco a pouco foi se movendo para centro do poder institucional, o que lhe permitiu tornar-se, no final da década, uma das expressões religiosas de maior visibilidade social no campo religioso brasileiro. Tendo surgido nos Estados Unidos, inspirada no movimento pentecostal das igrejas protestantes de reavivamento espiritual, chega no Brasil em 1968, trazida por padres jesuítas. Centrada no "batismo no Espírito Santo", a RCC enfatiza a libertação individual que deve se operar na vida de cada cristão pela ação do Espírito. Como observei num artigo recente em que relaciono a experiência do catolicismo da libertação com a RCC, creio que esta se aproxima ao modelo de cristianismo que Ernst Troeltsch (1931, p. 69-72) definiu como mistico, enquanto as CEBs nos remeteriam para o modelo da seita/comunidade.

Em relação às romarias, no entanto, a RCC não vai promover santuários dedicados ao Espírito Santo, como se poderia esperar. Mas vai, isto sim, eleger Maria como objeto central de suas peregrinações. Entre as peregrinações marianas, no entanto, serão privilegiadas às que conduzem aos locais de aparições recentes. Ou seja, se Lourdes e Fátima, pela sua abrangência internacional e controle institucional, são apresentadas como modelos de santuários para o catolicismo romanizado, Medjugorje será a grande referência para a RCC. Essa experiência, no entanto, não fica restrita a seu espaço geográfico, na Bósnia - para onde todos os anos milhões de peregrinos se deslocam, entre os quais se constata uma predominância de carismáticos católicos - mas é replicada em inúmeros outros lugares em todo o mundo (Steil, 1995, 2001). É a partir destas referências que buscamos compreender as aparições de Nossa Senhora em Taquari não como uma conseqüência direta do movimento carismático católico, mas como um pólo condensador de uma experiência que perfomatiza, em nível local, o espírito do tempo que valoriza os elementos míticos de uma espiritualidade difusa e eclética. Mas onde aparecem também outros atores que acionam os 
significados que são produzidos no contexto das outras formas de catolicismos que vimos analisando. ${ }^{10}$

O que vamos encontrar em Taquari, no entanto, não é uma "romaria carismática”, mas sim um evento onde a arena de disputas dos significados condensados e reelaborados quotidianamente em torno de Maria se evidencia de uma forma nova. A incorporação de uma nova forma de expressão do catolicismo redefine a correlação de forças dentro do campo religioso católico. De modo que, em Taquari, fica claro, desde o início do evento, que a presença dos carismáticos redefine as possibilidades das alianças e a natureza dos conflitos. Franciscanos imbuídos de valores e visões do catolicismo da libertação, bispos e clero guardiães da ortodoxia romana, católicos devocionais e carismáticos podem ser identificados nesta arena em que se transforma o evento das apariçōes, com o afluxo intenso de peregrinos no local e com a produção do evento na imprensa do estado.

Nossa Senhora aparece a crianças pobres, dentro de um contexto semirural, na periferia de uma pequena cidade, com um população predominantem ente açoriana e portuguesa, que no Rio Grande do Sul sofre discriminação em relação àqueles que são considerados de "origem", podendo ostentar em sua carteira de identidade um sobrenome italiano ou alemão. Até aqui se repete a mesma estrutura que encontramos nas aparições marianas desde o século XIV: os pobres e iletrados, aqueles que a sociedade despreza, são os escolhidos aos olhos de Deus (Bouflet; Boutry, 1997; Christian, 1981). Poderíamos pensar numa atualização do mito judaicocristão de que "os últimos serão os primeiros", muitas vezes afirmado na tradição bíblica (Turner; Turner, 1978). Essa estrutura, no entanto, não se repete apenas para afirmar uma tradição ou prolongar o passado no presen-

\footnotetext{
${ }^{10}$ A Romaria de Nossa Senhora da Assunção, de Taquari, teve origem num evento de aparição mariana que ocorreu em 1988, no período da Semana Santa, quando um número expressivo de fiéis, assim como de jornalistas e curiosos, passaram a freqüentar a localidade de Rincão São José, na periferia semi-rural do município. Hoje, a romaria de Taquari acontece na festa de Assunção, celebrada anualmente no segundo domingo de agosto, quando o santuário chega a receber em torno de 20 mil romeiros.
} 
te, mas surge como uma medição e um instrumento para interpretar e incorporar as novas e contemporâneas formas de viver a experiência católica.

A ênfase do catolicismo carismático no Espírito Santo não pode ser dissociada da devoção a Maria, igualmente enfatizada. Poderíamos pensálas como signos que condensam duas estruturas de significados presentes na experiência religiosa contemporânea. Enquanto o Espírito Santo remete a uma espiritualidade de caráter mais subjetivo ou místico, no sentido dado por Troeltsch (1931) a essa categoria (Steil, 1999, p. 67-73), a devoção a Maria permite uma experiência mais objetiva e interpessoal com o sagrado. Ela aparece como uma pessoa fora do self, que interpela e toma forma numa alteridade objetiva, enquanto o Espírito Santo aparece fundamentalmente como uma energia, uma força que se manifesta na interioridade do self de cada um. Um meio de acesso direto ao poder divino e à inspiração mediante os "dons e carismas" do Espírito (Csordas, 1997, p. 312). De modo que, se podemos tomar a RCC como uma forma de atualizaçáo da gnose no campo católico,como a entende Otávio Velho (1998), num sentido mais abrangente do termo, também podemos ver como uma forma de reiteração da tradição católica, centrada na idéia de sacramento, como a compreende Pierre Sanchis (1986). Ou seja, as aparições remetem a uma presença física ou sacramental do sagrado no mundo, enquanto os dons e carismas do Espírito trazem para o campo a tendência atual de uma religiosidade mística e individualista.

Essas experiências são expressas em dois rituais que são centrais na performance da RCC: as grandes concentrações em praças públicas, que assumem um caráter de espetáculo, envolvendo cantores e ídolos mediáticos e as aparições de Nossa Senhora, nas quais os carismáticos tendem a ter uma posição de apoio, tornando-se seus principais divulgadores no campo católico. O que observamos nas romarias, por outro lado, é uma influência desta dimensão mais subjetiva e mediática, imprimindo em rituais tradicionais novas formas estéticas e perfomáticas de expressão religiosa. Se há, como vimos anteriormente, uma estrutura peregrínica e uma estrutura turística que se amalgamam nos rituais que vimos analisando, poderíamos também identificar, no contexto do catolicismo carismático, uma terceira estrutura, que seria a do espetáculo mediático. 


\section{CATOLICISMO DIFUSO E CULTURAL}

Há, ainda, uma outra forma de catolicismo a que precisamos nos remeter para compreender os múltiplos discursos e significados que se agregam nos signos e símbolos acionados nas peregrinações e turismo religioso. Mas, aqui, mais do que uma camada a ser sondada no nosso método de escavação, trata-se de um veio que atravessa e permeia capilarmente a cultura e a vida social como um todo. Estamos falando de um catolicismo difuso que se sedimentou na cultura ocidental através do calendário, das festas, dos valores e das sensibilidades cristãs construídas historicamente, mas vividas como se fossem naturais. Isambert (1982, p. 7) entende essa forma de catolicismo como uma espécie de "religião invisível", onde valores religiosos e culturais se misturam num todo indissociável. Uma dimensão da vida religiosa relativamente independente da hierarquia eclesiástica e dos quadros intelectuais que estão ligados a ela. No contexto do Rio Grande do Sul, essa forma difusa de religiosidade, diferentemente de outros estados do país, tem sido conformada não apenas pela tradição católica, mas também pela presença histórica na sociedade gaúcha de um protestantismo de migração, legitimado socialmente.

Duas expressões religiosas e sociais, situadas nos extremos dos ideaistipo que orientam nossa investigação - peregrinação e turismo - remetemnos a esta "religião invisível" ou cristianismo difuso: a romaria do Monge João Maria e o Natal Luz. Esses eventos têm em comum o fato de se realizarem fora do controle eclesiástico das instituiçōes religiosas, remetendo os peregrinos e/ou turistas para uma experiência do sagrado não normatizado ou racionalizado em dogmas teológicos ou prescrições morais. Ambos condensam, em performances muito diversas, sensibilidades religiosas que permeiam não só a cultura local, mas fazem parte de um "sentimento cristão" comum e muito mais abrangente. No entanto, se a primeira performance, a romaria do Monge, se realiza sem a mediação institucional, remetendonos ao conceito de communitas espontânea de Turner (1974), a segunda, o turismo motivado pelo Natal em Gramado e Canela, se realiza através da mediação das autoridades políticas do município, dos empresários locais e grandes corporações econômicas e financeiras. 
Mas enquanto a romaria do Monge performatiza a busca de um "sagrado natural" que possui um significado fundamental, como um refúgio si tuado no espaço, o Natal Luz realiza uma "representaçáo" do sagrado, na forma de espetáculo, que visa conduzir o turista a uma experiência interior de contato com sua própria sensibilidade. Se para o romeiro tradicional há uma simbiose entre o mundo e o sagrado, para o turista há uma fratura que permite ao mundo existir independente de qualquer fundamento sagrado. Ao se desvencilhar de sua "carga mundana material", o sagrado torna-se acessível na intimidade de cada um.

Essas duas maneiras de viver a religiosidade difusa na cultura apontam para um processo de diferenciação social e seleção cultural que se realiza pela ação das próprias experiências de peregrinação e/ou turismo religioso. Pode-se, então, perceber que, se de um lado há um sistema de crenças e valores cristãos que é comum na sociedade, as maneiras de vivê-lo e de se apropriar dele podem variar em cada contexto específico. Ou seja, se de um lado a modernidade cria uma religião invisível e difusa, também cria os meios e as mediaçóes para que se tenha acesso a ela.

\section{À GUISA DE CONCLUSÃO}

Como o leitor pôde perceber, buscamos, ao longo deste artigo, chamar a sua atenção para aquilo que permanece do catolicismo na cultura gaúcha, ao invés de ressaltar as suas mudanças. Na reveladora expressão de Marshall Sahlins, tentamos perceber "estruturas históricas de longa duração que se fazem presentes na atual conjuntura social e religiosa" (Sahlins, 1990, p. 15). Para isso, tomamos como ponto de partida contextos e eventos rituais do catolicismo que deixam transparecer essas estruturas históricas que, longe de se apresentarem como a sobrevivência do passado no presente, são, na verdade, contemporâneas e estruturantes de uma determinada visão de mundo e de um ethos cultural.

Nossa referência aos santuários e festas religiosas, portanto, não pretendeu fazer uma descrição fenomenológica deste tipo de culto no estado. Mesmo porque sabemos que, por mais que estendêssemos nossa lista, seria 
quase impossível dar conta do vasto elenco de lugares e eventos religiosos que compóem o calendário católico. Assim, a escolha dos eventos que troux emos à consideração do leitor teve um caráter eminentemente ilustrativo, na medida em que eles permitiram evocar uma série de elementos que apontam para aquilo que estamos compreendendo como uma estrutura de significados que se atualizanesses rituais do catolicismo. E, quando nos referimos ao catolicismo estamos na verdade nos remetendo a um intrigado sistema de práticas, significados, rituais e personagens que transitam por este universo religioso e que ultrapassam as fronteiras institucionais da Igreja e ortodoxia católicas. Atentos às convergências e aos mal-entendidos dentro do sistema, procuramos jogar um pouco de luz sobre o emaranhado de práticas, gestos e sentidos que se fazem presentes de forma contraditória e polifônica nestes rituais e eventos.

Talvez seja preciso, ainda, lembrar ao leitor que não entendemos que a nossa interpretação do catolicismo retrate a realidade. Nossa intenção foi apenas explicitar estruturas que configuram uma ideologia que naturalizamos através de modelos de tempo e espaço e relaçôes sociais que se objetivaramna sociedade gaúcha ao longo de mais de cinco séculos de predominância católica. Desse modo, esperamos ter contribuído para a superação de preconceitos estabelecidos a partir de um olhar positivista ou cientificista e perceber a racionalidade de atos, rituais, crenças e discursos de milhões de pessoas que definem seu lugar no mundo a partir dos recursos que o catolicismo coloca à sua disposição através de uma tradição de longa duração.

Ao trazer para a pauta as festas e eventos religiosos relacionados com locais de peregrinação, tocamos nos dois elementos mais importantes na definição de uma cultura: o tempo e o espaço. O tempo é uma construção social, afirmam aqueles que estudam os grupos sociais. Não está dado de antemão como um a priori universal, nem se apresenta como um vácuo, dentro do qual os indivíduos se situariam ao nascer. Ao contrário, ao virmos ao mundo somos incorporados dentro de um tempo preenchido por significados, aos quais temos acesso mediante a nossa participação nos eventos que o estruturam e o organizam em cada cultura.

O calendário é um dos instrumentos mais eficazes através do qual somos incorporados na cultura. Para além de nossas opções conscientes dian- 
te das possibilidades de caminhos religiosos ou não-religiosos que se apresentam hoje na sociedade pluralista em que vivemos, somos envolvidos por um calendário que nos remete constantemente a um imaginário religioso que subjaz à nossa experiência social e histórica. O Natal e a Páscoa, por exemplo, têm raízes culturais que ultrapassam em muito o seu sentido religioso estrito. Seu espírito penetra o tempo e envolve nossos sentimentos num clima de solidariedade e de festa para além dos rituais ou dogmas veiculados pelas instituições religiosas.

Esse tempo, carregado de significados, no entanto, não repousa no ar. Está, na verdade, associado a lugares que guardam a memória do vivido através de mitos e histórias que nos permitem construir uma conexão com o passado. Criam, assim, a percepção de uma continuidade entre as gerações que nos antecederam, a nossa e aquelas que virão depois de nós. Todas as sociedades pontuam a sua paisagem com lugares significativos. Locais onde nasceram seus líderes, campos de batalhas vitoriosas, túmulos de heróis, etc. tendem a se tornar focos de afluência de multidões. Mesmo aquelas sociedades que se afirmam não-religiosas estabelecem algum mapa de lugares densamente significativos, onde seus membros podem sempre de novo beber da fonte de uma tradição que tece diuturnamente os laços de sociabilidade e solidariedade entre aqueles que se reconhecem como um "nós". No Brasil, no entanto, esses lugares se concretizam para a massa de sua população principalmente em santuários que são depositários de imagens de santos, beatos e divindades.

Uma fotografia de 4 milhōes de romeiros se deslocando a cada ano pelo estado em busca de santuários e de eventos religiosos nos permite perceber que cada lugar de peregrinação se apresenta como parte de um texto interpretativo que está sendo escrito pelos romeiros e devotos que os freqüentam. E é através desta demarcação de tempos e lugares sagrados ou diferenciados que exercem sua capacidade de simbolização e recriação do mundo, ultrapassando a fronteira da natureza para penetrar no espaço da cultura, onde estão enredados numa teia de significados por eles mesmos tecida. Dar sentido aos tempos e lugares é, portanto, um ato de criação e de exercício de sua humanidade. 


\section{REFERÊNCIAS}

BASTIDE, Roger. Religion and the Church in Brazil. In: SMITH, Lynn; MARCHANT, Alexander (Ed.). Brazil, portrait of half a Continent. New York: Cornell University Press, 1951. p. 334-355.

BEOZZO, Oscar. Irmandades, santuários e capelinhas de beira de estrada. Revista Eclesiástica Brasileira, v. 37, n. 148, p. 741-758, dez. 1977.

BOUFLET, Joachim;BOUTRY,Philippe. Un signe dans le ciel: les aparitions de la Vierge. Paris: Bertrand Grasset, 1997.

CHÂTELLIER, Louis, A religiāo dos pobres: as fontes do cristianismo moderno sec. XVI-XIX. Lisboa: Editorial Estampa, 1995.

CHRISTIAN, William Jr. Local religion in Sixteenth-Century Spain. Princeton: Princeton University Press, 1981.

CSORDAS, Thomas. Language, charisma and creativity: the ritual life of a religious movement. Berkeley, Los Angeles: University of California Press, 1997.

DELLA CAVA, Ralph. Miracle at Joaseiro. New York: Columbia University Press, 1970.

ISAMBERT, François-André. Les sens du sacré: fête et religion populaire. Paris: Les Éditions de Minuit, 1982.

RIBEIRO DE OLIVEIRA, Pedro. Religião e dominação de classe: gênese, estrutura e função do catolicismo romanizado no Brasil. Petrópolis: Vozes, 1985.

SAHLINS, Marshall. Ilhas de história. Rio de Janeiro: Jorge Zahar, 1990.

. Historical metaphors and mithical realities: structure in the early history of the Sandwich Kingdom. Ann Arbor: The University of Michigan Press, 2000.

SANCHIS, Pierre. Uma identidade católica? Comunicaçôes do ISER, Rio de Janeiro, n. 22, p. 5-16, nov. 1986.

Debates do NER, Porto Alegre, ano 5, N. 5, P. 9-30, Junho 2004 
STEIL, Carlos Alberto. Aparições de Nossa Senhora, tradição e atualidade. Grande Sinal, v. 5, n. 49, p. 545-555, 1995.

O sertão das romarias: um estudo antropológico sobre o santuário de Bom Jesus da Lapa - Bahia. Petrópolis: Vozes, 1996. v. 19, n. 2, 1999.

. A Igreja dos pobres: da secularização à mística. Religião e Sociedade, Aparições marianas contemporâneas e carismatismo católico. In: SANCHIS, Pierre(Org.). Fiéis e cidadãos: percursos de sincretismono Brasil. Rio de Janeiro: EdUERJ, 2001. p. 117-146.

TROELTSCH, Ernst. The social teaching of the Christian Churches. New York: Macmillan, 1931.

TURNER, Victor. O processo ritual: estrutura e anti-estrutura. Petrópolis: Vozes, 1974.

TURNER, Victor; TURNER, Edith. Image and prilgrimage in Christian culture. Oxford: Basil Balckwell, 1978.

VELHO, Otávio. Ensaio herético sobre a atualidade da gnose. Horizontes Antropológicos, Porto Alegre, ano 4, n. 8, p. 34-52, jun. 1998. 